\title{
Ecosemiotics and cybersemiotics
}

\author{
Soren Brier \\ Royal Veterinary and Agricultural University \\ Rolighedsvej 23, DK-1958 Frederiksberg C, Denmark \\ e-mail: sbr@kvl.dk
}

\begin{abstract}
The article develops a suggestion of how cybersemiotics is pertinent to ecosemiotics. Cybersemiotics uses Luhmann's triadic view of autopoietic systems (biological, psychological, and socio-communicative autopoiesis) and adopts his approach to communication within a biosemiotic framework. The following levels of exosemiosis and signification can be identified under the consideration of nonintentional signs, cybernetics, and information theory: (1) the socio-communicative level of self-conscious signification and language games, (2) the instinctual and species specific level of sign stimuli signifying through innate release response mechanism and sign games, and (3) the level of structural coupling, signal recognition, and languaging, where cybernetic feedback loops evince differences. Signification and communication levels arise whenever autopoietic systems interpenetrate (1) with the language system's semiotic and the psyche's phenosemiotic processes based on imaging, emotion, and volition and (2) between the psyche's phenosemiotic and the body's endosemiotic processes. It is at these two levels that we have the ecosemiotic signification processes of nonintentional signs in nature. $\mathrm{Hu}-$ mans are linguistic cyborgs as animals are sign cyborgs because signs at different levels interpenetrate and form our embodied processes. Sign producing and interpreting capability has had selective influence on both animals and humans in evolution.
\end{abstract}

Nöth (2001) specifies the scope of ecosemiotics as having the semiotics of signification of nonintentional signs as crucial in this field since a big part of ecosemiosis is about perception of non-human signs and as such of non-intentional semiosis. A theory of semiotics, which not only deals with intentional signs of communication but also encompasses non-intentional signs, such as symptoms of the body and patterns of inanimate nature, is Peirce's semiotics. It breaks with the traditional dualistic epistemological problem of first order science by 
framing its basic concept of cognition as signification in a triadic semiotic philosophy.

Peirce's triadic semiotics is integrated in the framework of his evolutionary cosmology, consisting of the three sub-theories of tychism, the theory of chance as an influence in the universe, agapism, the thesis that sympathy (or "evolutionary love") is "the great evolutionary agency of the universe", and synechism, which states that there is continuity from mind to matter (cf. Peirce 1992: xxii). According to Peirce, the three universal categories of Firstness, Secondness, and Thirdness are not only to be found within the perceiver's mind, but also in the nature perceived. The theory of tychism states that chance events, which belong to the category of Firstness, evince an evolutionary tendency to take habits and thus to evolve to Thirdness. The chaos of mere chance events, which characterizes Firstness is not seen as the lack of law, as in mechanicism and rationalism, but as something full of potential qualities to be manifested individually in Secondness and as general habits in semiosis in Thirdness.

It is interesting to note that Peirce, Bertalanffy, and Luhmann, in spite of much criticism of Hegel, are nevertheless influenced by this German philosopher. They are all concerned with the problem of how new hierarchical levels of natural existence can arise in an evolutionary process that should be describable as a regular interaction of some basic dynamic categories. The genius of Peirce found a way to describe such processes in perception, thought, and communication by means of his three universal categories, which are so fundamental that it is evident that these also function in nature independently of the human mind. A fundamental connection between mind and nature beyond mechanicism is then established.

A similarly fundamental model (but of a very different foundation) has been proposed within the cybernetics pan-information paradigm based on an objectivistic concept of information. For instance, Stonier (1997) sees the infon as a kind of fundamental particle, i.e., the dynamic organizational force in nature and evolution. However, Stonier has no explicit general framework like Peirce's metaphysical conception of Firstness, Secondness, and Thirdness with semiotic qualities even at the level of evolution guiding the evolutionary development of natural laws in a teleonomic process working over space-time magnitudes so powerful that it is beyond human perception. Peirce's semiotics is a radical turnaround both from the Kantian tradition, from rationalism and from dualistic mechanicism as originally laid down by Descartes. 
In times of search for new foundations of sustainability and understanding of the place of humans and their role and possibilities in nature, it is worthwhile exploring the foundations, possibilities, and limits of ecosemiotics. In this context, I would like to discuss the relevance of the concept of organizational closure and embodiment, which has been developed in the theory of autopoiesis and in second order cybernetics, and has become an integral part of Niklas Luhmann's general systems theory. The present article is based on results reported in Brier $(1999,2001)$.

\section{Luhmann's triadic autopoietic systems}

Luhmann has generalized the concept of autopoiesis to comprise both the psychic and biological systems of an individual and the sociocommunicative systems of a group. He views the psyche as a silent inner system, a closed system of perception, emotions, and volitions. The psychic system of the individual is characterized by autopoiesis and organizational closure. A socio-linguistic system has to be created for communication to happen. Socio-communication between individuals is an organizationally closed system, which evinces autopoiesis. Only communication communicates. Social systems are communicative systems with human bodies and minds as their environments. There are hence three organizationally closed systems, the biological, the psychical and the socio-communicational one, to make communication possible.

To Luhmann (1995), communication is a sequence of three selections, of information, of utterance, and of meaning. The selections of information and of utterance have to be made by what we traditionally call "the senders". The selection of meaning has to be made by the receivers, who choose their understanding of the signs produced. In addition, there is a fourth selection when the message is connected to present practice. A message is produced successfully when the receiver says something that the sender chooses to understand as a confirmation of understanding of the sender's first message.

Luhmann's view of information is partly based on Shannon and Weaver, but Luhmann does not believe in the possibility of applying this model outside the sphere of human socio-communication. Information comprises the quantitative aspect of a meaningful human context and it is combined with utterance and meaning. Luhmann stresses 
that both the sender and the receiver have to make their choices to produce a meaningful message. Information is a choice related to subject matter, utterance is a choice pertaining to the way of saying something, and meaning is a choice of the hearer's interpretation and it depends on the hearer's evaluation of the human context. It is especially in the social communicative construction of meaning that Luhmann's theory is relevant to semiotics.

\section{The cybersemiotic view}

Our inner mental world is a way of representing our bodily interactions with the environment and the construction of a sphere of signification by means of our body. What Spinoza calls conatus, i.e., self-value and self-interest in preserving the individual's and species' self-organizing structure, is fundamental to the living systems' ability to signify. But this individual sphere of signification is again perturbed by the interactions starting with mating, rearing of the young, and competition for hunting territory, group hierarchy, or co-operation in food gathering and hunting. These activities first generate sign games and later, in humans, language games. Prerequisites of constructing meaningful and informative messages are autopoiesis, signification, and conatus with motivation and intentionality. It is only within this triad that the selections of information, utterance and meaning are possible. My theory is then that sign and language games are based on the interpenetration of autopoietic systems. Luhmann, in my view, had still problems to produce a concept of meaning that relates deeply to the flesh, blood, and life (conditions) of biological systems and the existential conditions of human consciousness. Phenomenology and hermeneutics have more to offer at this point when seen as part of a pragmatic language philosophy, like Wittgenstein's language game theory and Lakoff and Johnson's embodied cognitive semantics combined with ethology within biosemiotic framework (further argued below).

Extended in this way, Luhmann's three autopoietic systems are indeed necessary for the creation of a message, but Luhmann's functionalism does not adequately take into consideration the role of the body and the mind in the production and meaning of social communication. A way of escaping from this theoretical impasse is to view the interpenetration between the three organizationally closed systems in a semiotic framework. Signs acquire meaning where the systems inter- 
penetrate, which has been Luhmann's term for the interplay between biological autopoiesis, psychic closure and the socio-communicative system with its own closure at the social level.

Meaning is then seen as being generated by the interpenetration of the biological, psychical, and socio-linguistic systems. For example, language is a part of the socio-communicative system, but it does not really get a meaning before it interpenetrates with the psychic system, indicating differences of emotion, volition and perception, and 'putting words' into our silent inner being. However, our cognitive, emotional, and volitional qualities would only have a weak connection to reality if they were not connected to the survival of the living systems' organization in its interacting with the environment's differences in the development of a signification sphere in the evolution of the species. Biosemiotics and the theory of metaphor have given evidence of the importance of embodiment in semiosis (further argued in Brier 2001). For the connection between the biosemiotic (ethologically based) concept of motivation and the motivational concept of embodied cognitive semantics and the details of a comprehensive cybersemiotic model of the relevant determinants see Brier (2000). As argued in this context, a phenomenological-emotional approach is necessary to understand how meaning is produced, which is consistent with Peirce's theory of feeling as an attribute of Firstness.

Cognitive phenomena have either been explained by functionalist cybernetic or by meaning based semiotic approaches. None of them give a complete explanation. Peirce has pointed out the continuity between human reasoning and machine operations. Solving logical problems and algorithms is equal to a mechanical process that obeys predetermined rules. This is what human nature has in common with mere machines, according to Peirce, who wrote:

All that I insist upon is, that, in like manner, a man may be regarded as a machine which turns out, let us say, a written sentence expressing a conclusion, the man-machine having been fed with a written statement of fact, as premiss. Since this performance is no more than a machine might go through, it has no essential relation to the circumstance that the machine happens to work by geared wheels, while a man happens to work by an ill-understood arrangement of brain-cells. (Peirce CP 2.59)

Creative work is needed to construct logical systems, but this does not mean that logical reasoning is more fundamental than life and consciousness. For Peirce, semiosis is universal. It is the prerequisite of science and philosophy, of knowledge as such. Knowledge systems un- 
fold from our bio-psycho-socio-linguistic conscious being. Their function is to help us orient (ourselves) in the world and help us act together in the most fruitful way, but they do not explain us to ourselves.

Prigogine's views of complexity (cf. Prigogine \& Stengers 1984) and Peirce's view of chaos and chance are compatible, but Peirce's view that we cannot draw a fundamental distinction between mind and matter is still more fundamental. There are no good reasons why the inner world of cognition, emotion, and volition should not be accepted as being as real as the physical world and our cultural world of signs and meaning (including Popper's world 3 of objective knowledge). Embodied life has to be an essential part of reality. We are thinking in, or maybe even with, the body.

Cybersemiotics deals with the metaphysical background of both cybernetics and semiotics. It brings cybernetics and semiotics in relation to each other, especially in their modern versions of second order cybernetics and the theory of autopoiesis on the one hand and Peircian biosemiotics on the other. Furthermore, cybersemiotics considers motivation and embodiment as important parts of biosemiotic communication. Embodiment and motivation are important common denominators of animal sign games and of human language games, thus integrating biosemiotics with the cognitive-semantic embodied metaphor theory of Lakoff and Johnson and with Wittgenstein's later language philosophy.

One of the foundations of cybersemiotics is Luhmann's conception of a message consisting of information, utterance, and meaning. However, Luhmann did not elaborate the semiotic process of signification in order to understand the production of meaning. His theory of the sociocommunicative human being consisting of three autopoietic systems has been used in cybersemiotics to distinguish between (1) the languaging (Maturana) of the biological system (coordinations of coordinations of behaviour), (2) the sign games (Brier) of the bio-psychological system, and finally (3) the language games (Wittgenstein) of the self-conscious linguistic human (Cyborg) through generalized media in the sociocommunicative systems (Luhmann). Luhmann's systems theoretical conception has thus been extended by a semiotic dimension, and his theory is being placed in the Peircean triadic metaphysics.

It is obvious that language games arise in social contexts where humans use their minds to coordinate their actions with other humans. Filtered through culture and language, some of these language games are about nature. Humans also participate in emotional and instinctual biological sign game (further argued in Brier 1995) of paralinguistic signs, whose origin is in the evolution of signification processes in liv- 
ing systems. Furthermore, mind and body are in internal communication. Kull (1998) discusses psychosomatics as a form of communication between culture and internal nature, and similarly, Luhmann focuses on communicative interaction between the body and human culture.

It was Sebeok (1976: 3) who introduced the term endosemiosis to designate semiotic processes taking place within organisms, in contrast to exosemiosis, which refers to sign process that occur between organisms. Uexküll et al. (1993) define endosemiosis as any semiotic interaction at a biological level. If ecosemiotics designates signification processes in which non-intentional signs are involved, the term exosemiosis that refers to communication by means of intentional signs should be considered in opposition to it.

How should then the semiotic interaction between the biological and the psychological systems then be called? Luhmann postulates that body and psyche are autopoietic systems which are closed to each other, but which interact by interpenetration. The semiotic aspect of this interpenetration of body and psyche can be called for intrasemiosis.

Finally I will suggest that we call the wordless inner semiotic processes of the mind or psyche for phenosemiosis, as there are the perceptual, emotional, volitional signs often in the form of images and patterns, which the phenomenologists takes as the basic elements of our inner world.

Today we know that there are semiotic interactions between the hormone systems, the transmitters in the brain, and the immune system, and it is known that these interactions are very important for the establishment of the second order autopoietic system, which a multicellular organism constructs. Parts of this system are the cells that are themselves autopoietic systems. However, we do not know very well what the relations between our lived inner world of feeling, volitions, and intentions and this system are. It seems that certain kinds of attention on bodily functions, such as imaging, can create physiological effects. As mentioned above, this is partly due to substances that have an endosemiotic sign effect on organs and specific cell types within the body. Such processes are very significant to the embodiment of the human mind and somehow they are released by intrasemiotic sign games. For example, our state of mind is determined by our body posture through the tightness of our postural muscles. We also know that our hormonal level influences our sexual and maternal responses. Fear, for example, causes a series of chemical processes that change the state and reaction time of several body functions. There is still a lot we do not yet know about the interaction between these systems. 
The nervous system, the hormonal system, and the immune system are incorporated within an enormous self-organized sign web. Sign production in autopoietically closed living systems does not allow for any real opening of the system for the reception of signs as such, and semiotics in itself has hardly considered evolutionary the role of embodiment in the creation of signification. According to the cybersemiotic approach, signs are produced when the systems interpenetrate, and the closed biological, psychic, and socio-linguistic systems produce different kinds of semiosis through different types of interpenetration with structural couplings and cybernetic "languaging", as Maturana and Varela (1980) call it.

The theory of autopoiesis describes the two interpenetrating systems as black boxes which are closed to each other, but Maturana points out that interpenetration develops as a coordination of coordinations of behaviour, which he calls languaging. In the process of languaging, reciprocally structural couplings take place between he the two systems, which allow for sign production and exchange. Maturana's concept of languaging through reciprocal structural couplings thus describes the bio-psychological interaction between two individuals in a social group. The relation to the environment is directed through unilateral structural couplings. However, it is not the sign or the language game as such that is central to languaging but the cognitive coupling, which constitutes the necessary connective coordination for communication to develop as a signification system with its own organizational closure. It is therefore necessary to distinguish between languaging and sign games at the level of reflexes and instinctual movements. Perception, which elicits reflexes, is independent of motivation, whereas perception of sign stimuli depends on motivation, which has to do with instinctual sign games. Ethologists have shown how certain instinctual movements become ritualized and get a signal release value for instinctive behaviour as "sign-stimuli". Lorenz (1973), in particular, realized that emotions have to be connected with the production of instinctual movements. These insights give evidence of how the connection between signs and internal or phenomenological understanding is constructed. Lakoff (1987) and Lakoff \& Johnson (1999) have further shown how metaphorical processes can explain this mechanism of bodily meaning and how it encompasses socially and culturally produced signs.

Based on ethology and biosemiotics I have shown that cognition manifests as embodied semiosis, which is motivated in our biological social interest as a powerful creator of structure and meaning in our 
sphere of signification. Most animal behavior is as unconscious as most of our linguistic categorization and use of metaphors. Ethologists had to realize that motivation is not a physiological process (see also Ellis et al. 1998). As we are born, we grow into social communication; our psyche is perfused with signs. Sign games develop into language games. Our mind is "infected" with language, and we become semiotic cyborgs or what we call humans. We are born as animals with the capacity of constructing interpenetrations between psychic and socio-communicative systems. We create internal interpretants that are meaningful to us because of the mutual structural couplings of languaging established in evolution.

Along these lines, my preliminary model combines semiotics with systems theory in its advanced second order version, integrating in complementary ways pragmaticist semiotics, cognitive semantics, and language game theory. I am aware that my integration of semiotics, cognitive semantics, and Luhmann's three organizationally closed systems goes beyond Luhmann, but I think this extended theory is necessary for obtaining a more comprehensive perspective of the relation between ethology and cognitive embodied semantics in a biosemiotics framework (Brier 2000).

Lakoff \& Johnson's research can be seen as a bridge between the biological and the cultural levels in cognition and communication. Their concept of embodiment can be expanded beyond such schemes as up-down, in-out, front-back, container-path to embrace further signification spheres of living systems. The cybernetic view of embodiment should be developed further on the basis of Lorenz's (1970-71) and Tinbergen's (1973) ethological research paradigm, Uexküll's presemiotic phenomenological biology, and Maturana \& Varela's theory of autopoiesis.

We have become self-conscious human beings in and through language. Pre-linguistic infants are only animals with a human potential. Only the social web of languaging between members of the same species and the sign games of emotional awareness form the self-conscious linguistic human being. Loosely inspired by Donna Haraway and Lucia Santaella, I accept the human being as a linguistic Cyborg. It is a biopsychological being "infected" by language, with the consequence that its nervous system and awareness have been affected by irreversible changes. The advantage that the socio-communicative hominids gained from the structural coupling of language games and generalized media is so enormous (cf. Deacon 1997) that language and linguistic activities became an important selection pressure in early human evolution. This 
pressure left its influence on the bodily development of humans towards better anatomical structures to support language production. As the human brain and skull grew in size, children were born with increasingly neotenic features to make them more susceptible to cultural linguistic programming. The instinctual system becomes more and more open to programming through personal experience. Thus, the advantage of learning processes is that they pertain better to the actual environmental and social situation and not only to those situations of the past that were instrumental in selecting our genes.

This system of adaptation in early life, combined with the mental tool of conceptual communication and later with inner thought, was so advantageous for the survival and proliferation of the species that we developed into those linguistically-culturally programmed cyborgs that we call today human beings. It is important to keep Heidegger's and Wittgenstein's insight in mind that we are not only linguistic beings who think, learn, communicate, and co-ordinate through language, but also that it is as much language that thinks in us. As much as we speak a language, we are also spoken by language, which makes it difficult for us to think beyond language. We have to begin our search for knowledge realizing that our mind is semiotic. It is built on, or from, semiotic processes, already at the animal stage. Being in permanent semiosis with other social beings, with nature, and with ourselves, we can hardly expect to gain knowledge beyond our own sphere of signification. We can slowly increase our cultural sphere of signification through science and philosophy, but it is doubtful whether we can ever explain it in a way that we can predict or even reconstruct it from scratch.

Cybersemiotics accepts the epistemological premises of internal realism created by Putnam and used by Lakoff (1987), which work well with Peirce, Prigogine, and Luhmann: we observe the universe from our world - or rather signification spheres. What we can do is to examine ourselves as bodies and to develop inner awareness of our language, society, and through ecosemiotics reflect on our understanding of our natural environment. Then we can gradually try to discover the necessary prerequisite for our world to function the way it does. There is no unique and safe way of doing this. As Peirce and Popper have recognized, it must be done by bold hypotheses (abduction), by logical thinking to determine internal consistencies and concise consequences (deduction), and by testing both the empirical (induction) and the theoretical coherence of what we at present believe to be solid knowledge. Cybersemiotics is the proposal of a model to understand 
ourselves, our society and our environment (through ecosemiotics) until something better comes by.

\section{Conclusion}

The cybersemiotic framework combines Peirce's non-reductionistic, non-mechanical, evolutionary, and triadic semiotic framework, second order cybernetics, the theory of autopoiesis, Luhmann's theory of socio-communication, cognitive semantics in Lakoff \& Johnson's embodied version, and Wittgenstein's theory of meaning construction in language games. In its framework, semiosis is the key to the understanding of cognitive and communicative processes. Evolution is defined as the creation of material, psychological, and cultural habits. Meaning is seen as being embodied in biosemiosis and investigated from the points of view of cognitive semantics, autopoiesis theory, and ethology. However, with the new cybernetics and Uexküll, the embodiment of meaning must be considered as having a much broader scope than its embodiment in the nervous system, in neurotransmitters, and hormone, or immune systems, where it is appears in the form of reactions to the sign substances that they secrete. As Fogh Kirkeby (1997) suggests, we should look at the human body-mind or bodythought as a complex phenomenological dynamical system, including the construction of the environment and the other (body-mind) systems that make it possible for signification to appear.

Since signification does not only pertain to the environment, but also to the perception of other members of the species in cultural and proto-cultural behavior as well as to self-perceptions, I use "eco-" as a prefix to the signification sphere when it pertains to nature outside the species in question.

Language is about nature, culture, and our inner world of emotions, volitions, and rationality. Ecosemiotics investigates language insofar as it shows how living systems represent nature in spheres of signification that extend to language games in culture. Cybersemiotics shows that the bases of such eco-language games are the eco-signgames of animals, combined with a sphere of signification, originally called "Umwelt" by Uexküll, and created through evolution. Their basis is further an intricate interplay between the living system and its environment, establishing what Maturana and Varela call structural couplings. The sphere of signification is a useful model of nature 
showing how living systems have existed and evolved through millions of years. This is also true of the human species whose language is inherently connected with the ecology of human culture. Cultures are collective ways of securing the ecological survival of a social system. Cultures also have a sphere of signification, which is in mutual determination with ecosemiosis. This sphere of signification is largely created by the life forms and language games of that culture, be they animistic, as in a hunter-gather society, or materialistic, energetic, and informational, as in a post-industrial knowledge society.

In sum, the present analysis proposes to distinguish between the following three spheres of eco-signification and one domain of ecostructural couplings:

(1) There is first the cultural sphere of eco-signification.

(2) There is then a species-specific sphere of eco-signification.

(3) Every individual has his/her own eco-signification sphere.

(4) There is the structural domain of eco-coupling, as described in theory of autopoiesis and second order cybernetics, which can be found at the core of Uexküll's Umwelt theory.

These four levels depend on one another. Although they do not necessarily dovetail perfectly into one another, they are all essential constituents of our eco-semiotic system.

\section{References}

Brier, Søren 1995. Cyber-semiotics: On autopoiesis, code-duality and sign games in bio-semiotics. Cybernetics \& Human Knowing 3(1): 3-25.

- 1999. Biosemiotics and the foundation of cybersemiotics: Reconceptualizing the insights of ethology, second order cybernetics, and Peirce's semiotics in biosemiotics to create a non-Cartesian information science. Semiotica 127(1/4): 169-198.

- 2000. On the connection between cognitive semantics and ethological concepts of motivation: A possible bridge between embodiment in cognitive semantics and the motivation concept in ethology. Cybernetics and Human Knowledge 7(1): 57-75.

- 2001. Cybersemiotics and Umweltlehre. Semiotica 134(1/4).

Deacon, Terrence W. 1997. The Symbolic Species: The Co-Evolution of Language and the Brain. New York: Norton.

Ellis, Ralph D.; Newton, Nakita 1998. Three paradoxes of phenomenal consciousness: Bridging the explanatory gap. Journal of Consciousness Studies 5(4): 419-42.

Kirkeby, O. Fogh 1997. Event and body-mind: An outline of a post-postmodern approach to phenomenology. Cybernetics \& Human Knowing 4(2/3): 3-34. 
Kull, Kalevi 1998. Semiotic ecology: Different natures in the semiosphere. Sign Systems Studies 26: 344-364.

Lakoff, George 1987. Women, Fire and Dangerous Things: What Categories Reveal about the Mind. Chicago: Chicago University Press.

Lakoff, George; Johnson, Mark 1999. Philosophy in the Flesh: The Embodied Mind and its Challenge to Western Thought. New York: Basic Books.

Lorenz, Konrad 1970-1971. Studies in Animal and Human Behaviour, 2 vols. Cambridge (Mass.): Harvard University Press.

- 1973. Die Rückseite des Spiegels: Versuch einer Naturgeschichte menschlichen Erkennens. Piper: München.

Luhmann, Niklas 1990. Essays on Self-Reference. New York: Colombia University Press.

- 1995. Social Systems. Stanford: Stanford University Press.

Maturana, Humberto R.; Varela, Francisco J. 1980. Autopoiesis and Cognition: The Realization of the Living. Dordrecht: Reidel.

Nöth, Winfried 2001. Ecosemiotics and the semiotics of nature. Sign Systems Studies 29(1) (this vol.).

Peirce, Charles S. 1931-1958. Collected Papers. Vols. 1-6, eds. C. Hartshorne \& P. Weiss, vols. 7-8, ed. A.W. Burks. Cambridge (Mass.): Harvard University Press. [Quoted as: CP.]

- 1992. The Essential Peirce: Selected Philosophical, vol. 1 (1867-1893), eds. N. Houser \& C. Kloesel. Bloomington: Indiana University Press.

Prigogine, Ilya; Stengers, Isabelle 1984. Order Out of Chaos: Man's New Dialogue with Nature. New York: Bantam.

Sebeok, Thomas A. 1976. Contributions to the Doctrine of Signs. Bloomington: Indiana University Press.

Stonier, Thomas A. 1997. Information and Meaning: An Evolutionary Perspective. Berlin: Springer.

Tinbergen, Niko 1973. The Animal in Its World. London: George Allan \& Unwin.

Uexküll, Jakob von 1957. A stroll through the worlds of animals and men: A picture book of invisible worlds. In: Schiller, Claire H. (ed.), Instinctive Behavior: The Development of a Modern Concept. New York: International University Press, 5-80.

Uexküll, Thure von; Geigges, Werner; Herrmann, Jörg M. 1993. Endosemiosis. Semiotica 96(1/2): 5-51.

Wittgenstein, Ludwig 1958. Philosophical Investigation, 3rd ed., transl. by G. E. M. Anscombe. New York: MacMillian.

\section{Экосемиотика и киберсемиотика}

В статье сделана попытка связать киберсемиотику с экосемиотикой. Киберсемиотика опирается на троичное деление автопойэтических систем (биологический, психологический и социокоммуникативный автопойэзис) Луманна и применяет его взгляд на коммуникацию в контексте 
биосемиотики. Учитывая неинтенциональные знаки, кибернетику и теорию информации, можно выделить следующие уровни экосемиозиса и означивания: 1) социокоммуникативный уровень сознательного означивания и языковых игр, 2) инстинктивный и видоспецифический уровень знаковых стимулов, означивающих посредством врожденного механизма реакции и "знаковых игр", 3) уровень структурного соединения, узнавания сигнала и "оязычивания", где циклы кибернетической обратной связи указывают на различия. Уровни означивания и коммуникации проявляются везде, где автопойэтические системы 1) перемешиваются с семиотическими процессами языковой системы и феносемиотическими процессами психики, опирающимися на представления, эмоции и волю, или 2) вторгаются между феносемиотическими процессами психики и эндосемиотическими процессами тела. На этих двух уровнях происходят экосемиотические неинтенциональные процессы означивания в природе. Люди являются лингвистическими киборгами точно так же, как животные являются знаковыми киборгами, так как знаки на разных уровнях перемешиваются и оформляют процессы воплощения. Способность производить и интерпретировать знаки оказывала в ходе эволюции селектирующее влияние как на животных, так и на людей.

\section{Ökosemiootika ja kübersemiootika}

Artiklis pakutakse välja ja arendatakse üht võimalust, kuidas seostada kübersemiootikat ökosemiootikaga. Kübersemiootika tugineb Luhmanni kolmetisele käsitlusele autopoieetilistest süsteemidest (bioloogiline, psühholoogiline ja sotsiokommunikatiivne autopoieesis) ja rakendab tema vaadet kommunikatsioonile biosemiootika kontekstis. Mitteintentsionaalseid märke, küberneetikat ja informatsiooniteooriat arvestades on tuvastatavad järgmised eksosemioosise ja tähistamise tasandid: (1) eneseteadvusliku tähistamise ja keelemängude sotsiokommunikatiivne tasand, (2) kaasasündinud reaktsioonimehhanismi ja "märgimängude" kaudu tähistavate märgistiimulite instinktiivne ja liigispetsiifiline tasand, (3) struktuurse sidustumise, signaali (ära)tundmise ja "keelestamise" tasand, kus küberneetilise tagasiside tsüklid osutavad erinevustele. Tähistamise ja kommunikatsiooni tasemed ilmnevad, kus iganes autopoieetilised süsteemid (1) segunevad keelesüsteemi semiootiliste ja psüühika fenosemiootiliste kujutlustel, emotsioonidel ja tahtel põhinevate protsessidega, või (2) tungivad psüühika fenosemiootilise ja keha endosemiootiliste protsesside vahele. Neil kahel tasandil toimuvad ökosemiootilised mitteintentsionaalsed tähistamisprotsessid looduses. Inimesed on lingvistilised küborgid nii nagu loomad on märgiküborgid, kuna märgid erinevatel tasanditel segunevad ja kujundavad kehastuvaid protsesse. Võime märke toota ja tõlgendada on evolutsiooni käigus avaldanud selektiivset mõju nii inimestele kui loomadele. 